\title{
Evaluation of the spontaneous combustion of coal (SCC) by using the R7o test method based on the correlation among intrinsic coal properties (Case study: Tabas Parvadeh coal mines, Iran)
}

\author{
Amir Saffari ${ }^{{ }^{*}}$; Mohammad Ataei ${ }^{1}$; Farhang Sereshki ${ }^{1}$ \\ ${ }^{1}$ Faculty of Mining, Petroleum \& Geophysics Engineering, Shahrood University of Technology, Shahrood, Iran.
}

The Mining-Geology-Petroleum Engineering Bulletin UDC: $536.5 ; 658.5$

DOI: $10.17794 / \mathrm{rgn} .2019 \cdot 3.6$

Original scientific paper

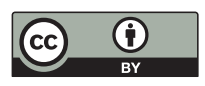

\begin{abstract}
The purpose of this research is to perform an evaluation of the spontaneous combustion of coal (SCC) in Tabas Parvadeh coal mines in Iran, by using the R7o test method based on a the correlation between intrinsic coal properties and the occurrence of its combustion. Firstly, the coal samples were collected from Parvadeh I to IV, and the intrinsic coal properties of the samples were tested. Then, the R7o test method, as the newest method for assessment of the SCC, was used. In the last step, the correlation between intrinsic coal properties and R7o test values was carried out. The results showed that the B 1 seam in Parvadeh II and the $\mathrm{C}_{1}$ seam in Parvadeh III have a high propensity of the SCC. The outcomes appear, an expansion of moisture, pyrite, vitrinite, and liptinite contents enhance the SCC tendency in these mines. The results obtained have major outcomes for the management of this phenomenon in Tabas Parvadeh coal mines.
\end{abstract}

Keywords:

sustainable development, spontaneous combustion of coal (SCC), Tabas Parvadeh coal mines, intrinsic coal properties, R7o test method.

\section{Introduction}

Coal is a non-renewable natural resource that is the most copious and economical fossil fuel resource in the world and it contains almost $90 \%$ of fossil fuel energy. Coal is a very affordable and reliable source of energy and it has assumed a basic role in the steadiness and development of the world's economy (Thakur, 2016; Medunić et al., 2018).

Regardless of all its benefits, coal mining, especially underground coal mining, is a very complex system and process. The harsh and unsafe working conditions are the most vital parameters that influence a coal mining process. The risks of underground mining are basic parameters, which ought to be considered in the structure and arranging venture of coal mines. Some huge hazards in underground coal mining can be outlined as subsidence, outburst, SCC, roof instability, passing through faulted and crushed zones, groundwater inflow, high methane gas content of the coal seam, and the presence of combustible coal dust. Along these lines, it is important to precisely distinguish the dangers included and to discover the approaches to estimate, avoid, and control them (Saffari et al., 2013; Sereshki and Saffari, 2016; Saffari et al., 2019a).

The SCC is a key safety issue in coal mining and has threats to sustainable development aspects in all stages

Corresponding author: Amir Saffari

amirsaffari5710@yahoo.com of coal mining (Song and Kuenzer, 2014). This phenomenon is the major reason for mischances bringing about the loss of lives, loss of profitable coal reserves, blockage of resources and capital, a decrease in heating qualities, coking properties, huge economic losses, and massive environmental contamination (Lang and FuBao, 2010). Thus, the SCC is an urgent problem that should be addressed and solved.

This process is an oxidation reaction that happens without an outside warmth source due to various complex exothermic reactions which, coal intrinsic characteristics are consistently alluded to as affecting the SCC (Saffari et al., 2017).

At the initial stage, the oxygen consumption of coal oxidation is small due to the low temperature and the insufficient contact between coal and oxygen. This stage will last for a period and the small heat produced by coal oxidation will constantly accumulate during this time. The heat accumulation increases the environment temperature and the higher temperature will accelerate the coal oxidation process. During the SCC process, coal oxidation will definitely produce some products such as $\mathrm{CO}$ and $\mathrm{CO}_{2}$, and it will also generate lots of heat released from the physical adsorption and chemical reaction in this oxidation process (see Figure 1).

The mechanism of low-temperature coal oxidation has been explored by numerous examinations yet total comprehension has never been acquired. Regardless of the fragmented comprehension of the mechanism and kinetics of coal oxidation, overall reaction paths have 


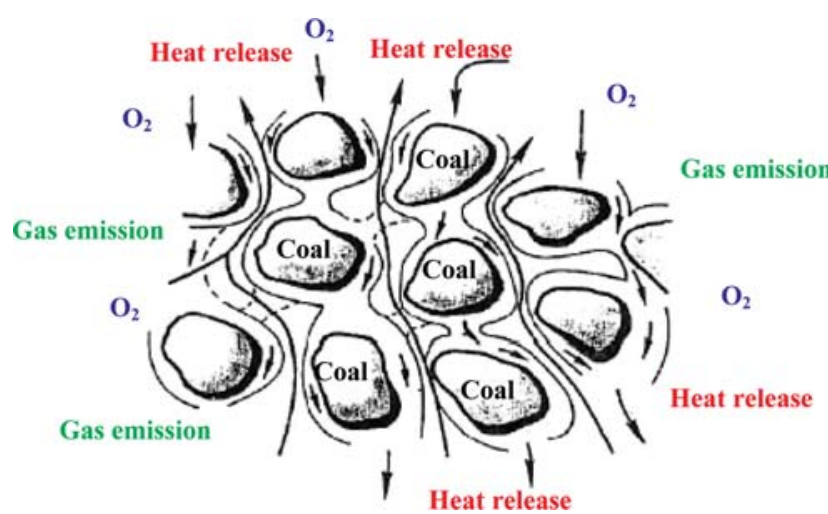

Figure 1: Fundamental phenomena occurring in the SCC process

reached a general consensus. Briefly, two parallel interaction sequences exist (Zhang et al., 2016 a):

- direct burn-off and

- adsorption sequence.

The burn-off step looks like the direct burning of solid fuels which is firmly reliant on temperature. This results in the direct formation of gaseous products including $\mathrm{CO}$, $\mathrm{CO}_{2}$, and $\mathrm{H}_{2} \mathrm{O}$ (Karsner and Perlmutter, 1982).

The adsorption sequence incorporates: (i) reversible physical adsorption ((see Equation 1); (ii) irreversible chemisorption of oxygen on the surfaces of pores and the formation of intermediate coal- oxygen complexes including peroxygen, hydroperoxide and hydroxyl species ((see Equation 2); (iii) the corruption of unsteady solid coal- oxygen complexes to gaseous products and the formation of stable solid compounds, e.g. carbonyl or carboxyl-containing species ((see Equation 3); (iv) the disintegration of stable mixes and the exposure of new active sites for oxidation (Wang et al., 2002), (see Figure 2) which is an extremely characteristic outline of the cooperation between coal and oxygen at a low temperature.

$$
\begin{gathered}
\text { Coal }+\mathrm{O}_{2} \rightleftarrows \mathrm{O}_{2} \text { Physical adsorption } \\
\mathrm{Coal}+\mathrm{O}_{2} \rightarrow \mathrm{O}_{2} \text { Chemical absorption } \\
\text { Coal }+\mathrm{O}_{2} \rightarrow \mathrm{CO}_{2}+\mathrm{CO}+\mathrm{H}_{2} \mathrm{O} \\
\rightarrow \begin{array}{l}
\text { Stable solid products, which tend to } \\
\text { decompose at temperatures above } 70
\end{array}
\end{gathered}
$$

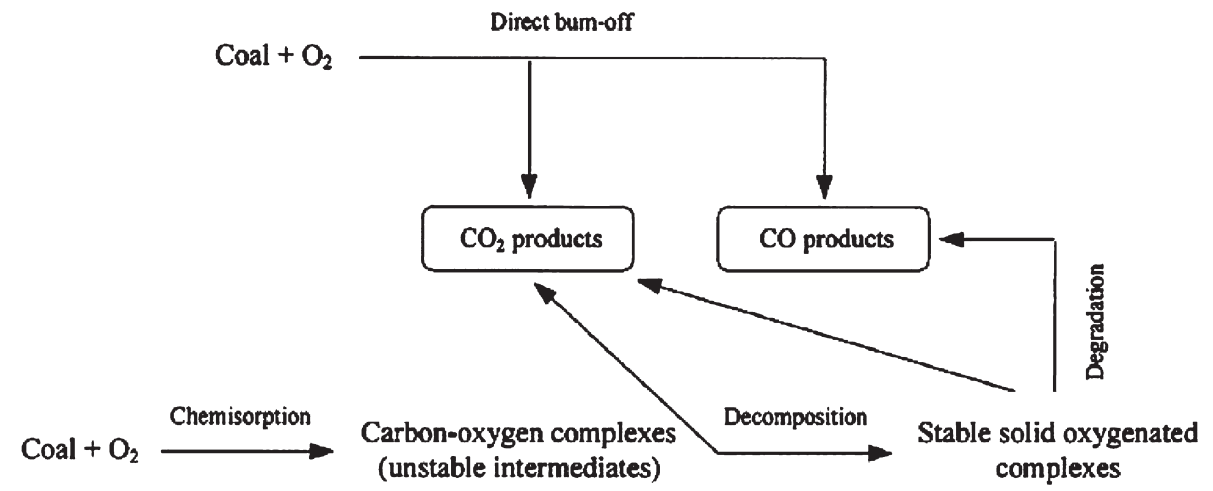

Figure 2: Two processes of low-temperature interaction of coal with oxygen (Wang et al., 2003)
However, not all coals are susceptible to auto-oxidation to a similar degree. Subsequently, the precise appraisal of the oxidative inclination is fundamental to design the generation and capacity abilities in mines. Awareness of the SCC potential before starting, during, and after coal mining operations has a significant effect on preventing the loss of sustainable development.

In this research, an attempt has been made to perform an evaluation of the SCC by using the R70 test method in Tabas Parvadeh coal mines (Iran). For this purpose, seven coal samples were collected and the intrinsic properties of these samples were determined and the R70 test method was done. The correlation study between the intrinsic parameters and $\mathrm{R} 70$ values was studied.

On December $25^{\text {th }}, 2016$, one complete block of the B1 seam in Parvadeh II was closed due to the SCC process in this seam. Despite the importance of this issue, this hazard is still not fully evaluated in Iran and there is no crisis management program. Therefore, in this study, the SCC propensity was measured experimentally using the R70 test method in Tabas Parvadeh coal mines. The results of this research are helpful to the assessment and management of the SCC issues in the Tabas Parvadeh coal mines.

This paper is outlined as follows: section $\mathbf{2}$ describes the R70 test method and the testing system, the case study is introduced in section 3, the experimental investigations are given in section 4 , the relationship between coal intrinsic characteristics and the R70 method are conducted in section 5, and finally, this paper concludes in section 6.

\section{Materials and methods}

\subsection{Coal samples and preparation}

For this study, seven coal samples (from Tabas Parvadeh coal mines) were freshly collected directly from the worked face of the mine. The conditions for collecting samples and transferring them to the laboratory to avoid the possibility of peroxidation, as well as the amount of sample required for each experiment, were carried out in accordance with the methods provided by Xuyao et al. (2011), and Zhang et al. (2016 b). 


\subsection{Experimental apparatus and method}

\subsubsection{R7o method}

One of the most familiar testing procedures of coals to indicate their propensity to the SCC is the adiabatic heating test (Cliff et al., 1996). This method is generally considered to simulate the in-situ condition whereby heat losses are not permitted to disseminate from the reaction vessel. Australian coalmine operations have been using adiabatic oven testing since the early 1980 s to rate the propensity of coal to spontaneously combust (Humphreys et al., 1981; Beamish et al., 2018). The R70 initial self-heating rate parameter normally obtained from these tests is rated using a relative scale. Evaluation of the resulting intrinsic SCC propensity rating enables a

Table 1: The R7o Classification (based on Queensland and New South Wales coal conditions)

\begin{tabular}{|l|l|l|l|}
\hline Class & $\begin{array}{l}\text { Queensland } \\
\text { R70 value } \\
\left({ }^{\circ} \mathrm{C} / \mathrm{h}\right)\end{array}$ & $\begin{array}{l}\text { New South } \\
\text { Wales R70 } \\
\text { value }\left({ }^{\circ} \mathrm{C} / \mathrm{h}\right)\end{array}$ & $\begin{array}{l}\text { Propensity } \\
\text { rating }\end{array}$ \\
\hline I & $\mathrm{R} 70<0.5$ & $\mathrm{R} 70<1$ & Low $(\mathrm{L})$ \\
\hline II & $0.5 \leq \mathrm{R} 70<1$ & $1 \leq \mathrm{R} 70<2$ & $\begin{array}{l}\text { Low-Medium } \\
(\mathrm{LM})\end{array}$ \\
\hline III & $1 \leq \mathrm{R} 70<2$ & $2 \leq \mathrm{R} 70<4$ & Medium $(\mathrm{M})$ \\
\hline IV & $2 \leq \mathrm{R} 70<4$ & $4 \leq \mathrm{R} 70<8$ & High $(\mathrm{H})$ \\
\hline V & $4 \leq \mathrm{R} 70<8$ & $8 \leq \mathrm{R} 70<16$ & Very High $(\mathrm{VH})$ \\
\hline VI & $8 \leq \mathrm{R} 70<16$ & $16 \leq \mathrm{R} 70<32$ & $\begin{array}{l}\text { Ultra High } \\
(\mathrm{UH})\end{array}$ \\
\hline VII & $\mathrm{R} 70 \geq 16$ & $\mathrm{R} 70 \geq 32$ & $\begin{array}{l}\text { Extremely High } \\
(\mathrm{EH})\end{array}$ \\
\hline
\end{tabular}

general appraisal of the possible likelihood of an SCC event to commence; however, it provides no indication of the timeframe in which an event can occur under the prevailing site conditions (Beamish et al., 2018).

The essence of the R70 method is as follows. The ground (with particle sizes of $<212 \mu \mathrm{m}$ ) coal sample is dried in an adiabatic oven at a temperature of $105-110^{\circ} \mathrm{C}$ for 16 hours under inert gas flow (nitrogen). At the same time, still under nitrogen, the coal is cooled to $40{ }^{\circ} \mathrm{C}$ in the same environment, and after that, it is stored in an oxygen-rich airflow at a temperature of $40^{\circ} \mathrm{C}$. Under the latter conditions, coal oxidation is being initiated and the processes of self-heating are observed. The average rate of coal heating from 40 to $70{ }^{\circ} \mathrm{C}$ is considered to be the index $\mathrm{R} 70\left({ }^{\circ} \mathrm{C} / \mathrm{h}\right)$. The higher the value of such an index, the more prone the coal is to spontaneously combust (see Table 1). Such a method is the most efficient one with respect to the simple characterization of coals propensity to oxidation and self-heating (Beamish et al., 2000, Arisoy and Beamish, 2015).

\subsubsection{Testing system}

Figure 3 shows a simplified diagram of the set utilized for the oxidation of coal. Figure 4 shows a schematic sample container (bomb) of the apparatus. The instrument consists of the following, which shown in Figure 5, and was made in the Shahrood University of Technology in Iran (Faculty of Mining, Petroleum \& Geophysics Engineering).

- a temperature-programmed adiabatic oven (used to control the temperature of the coal sample, whose temperature ranges from room temperature to $400^{\circ} \mathrm{C}$ with a precision of $1^{\circ} \mathrm{C}$ in the control);

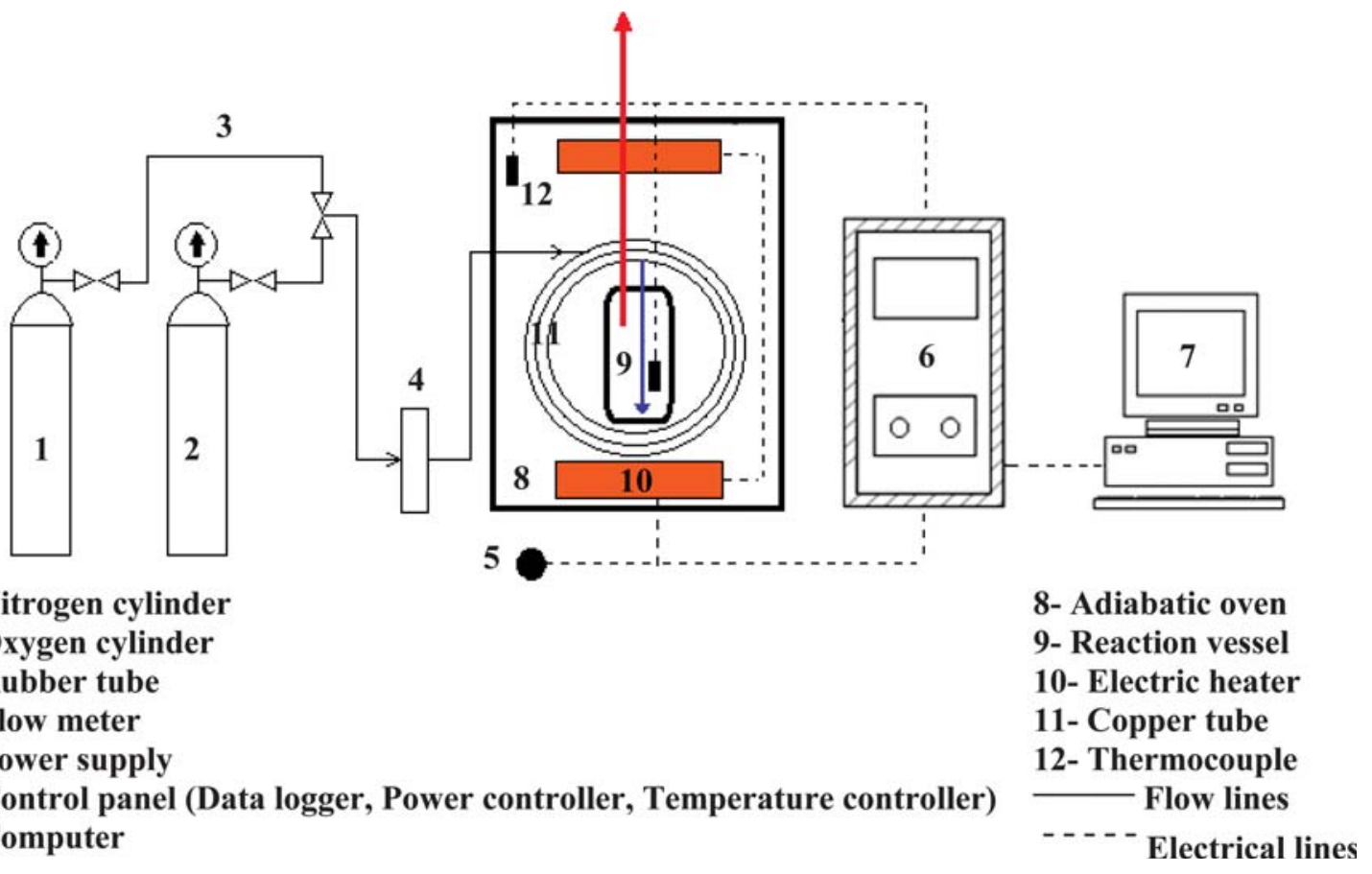

Figure 3: A schematic outline of the device applied for the oxidation test system 


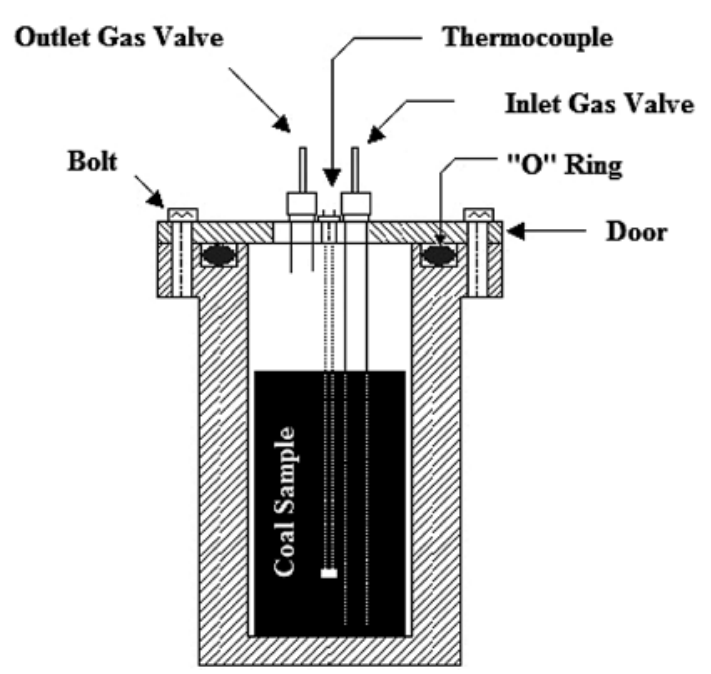

Figure 4: Sample container (bomb)

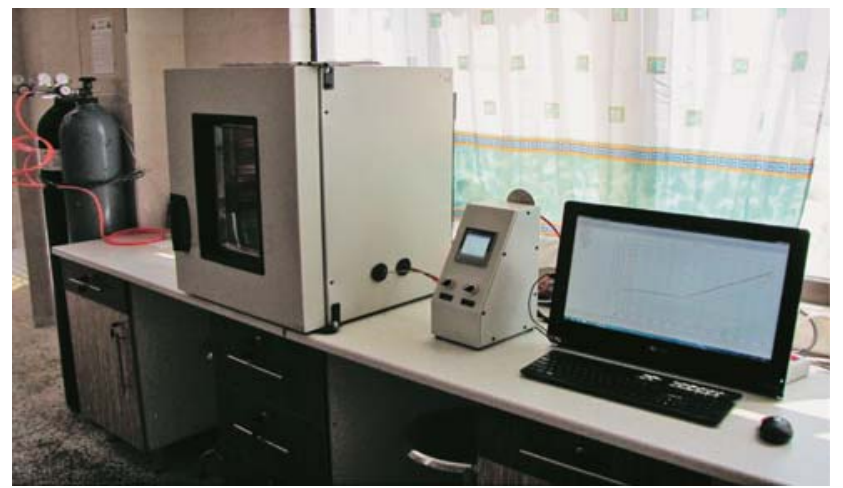

Figure 5: The testing system

- an electric heater;

- a fan;

- a sample container (bomb) (made of pure aluminum and is respectively connected with an inlet for air supply path, thermocouple for temperature measurement and an outlet for the air outlet path) (see Figure 4);

- a $15 \mathrm{~m}$ gas preheating copper tube;

- two thermocouples (Thermocouple \#1, used to monitor the oven temperature, and thermocouple \#2, used to measure the coal sample temperature);

- JUMO Dicon touch (control panel), which consists of:

- data logger (to record the temperature changes in the coal sample over time);

- micro controller (the programmed adiabatic oven was set to increase the temperature with a micro controller);

- a computer;

- a $50 \mathrm{~kg} \mathrm{O}_{2}$ gas cylinder (the air supply system);

- a $50 \mathrm{~kg} \mathrm{~N}$ gas cylinder (for drying the coal samples in $105-110^{\circ} \mathrm{C}$ for 16 hours);

- a pressure reducing valve;

- a flow meter.

\section{Case study: Tabas Parvadeh coal mines}

Two main basins of coal resources exist in Iran, one in Northern Iran and the other in central Iran, and both are well-known as the Alborz and Central basins, respectively. The Tabas coalfield is a major contributor to Iran metallurgical coking coal deposits, which is located in the Tabas block in central Iran (Ahangaran et al., 2011).

The Tabas coalfield district is about 1200 square kilometers, which is divided into different sub-zones, namely Parvadeh, Mazinu, and Nayband (Yazdi and Shiravani, 2004).

The Parvadeh coal deposit in the middle of the Tabas coalfield is located about $85 \mathrm{~km} \mathrm{SE}$ of the city of Tabas in the Southern Khorasan province in central Iran where the climate is hot and dry (see Figure 6). This deposit is structurally a long anticline which is oriented in an E-W direction. The study area is one of the very active and complicated areas from the viewpoint of tectonics and seismicity in Iran.

The Parvadeh basin includes five coal seams, namely $\mathrm{C} 1, \mathrm{C} 2, \mathrm{~B} 1, \mathrm{~B} 2$, and D; it is worth noting that the B and $\mathrm{C}$ coal seams are minable based on their quality and quantity, especially the $\mathrm{C} 1$ and $\mathrm{B} 2$ seams that have better qualities. The Tabas coal basin stratigraphic column is illustrated in Figure 7 (Sereshki et al., 2016; Afzal, 2018; Mohtasham Seyfi et al., 2018).

\section{Experimental investigations}

To evaluate the propensity of coals to the SCC, it is important to determine the coal intrinsic characteristics analysis to establish a relationship between these characteristics and R70 values, and the results of experimental investigations are given in Figure 8.

Each of the coal samples have been tested with R70 experimental setups. The R70 curves for Tabas Parvadeh coal mines samples are shown in Figure 9. Their respective R70 values are contained in Table 2 and were classified based on Table 1. It can be seen that coal Samples 4 and 6 have a high potential for the SCC. This high potential is due to high moisture content, high pyrite content, high vitrinite content, high liptinite content, and no inertinite content, in comparison to other samples. These values and ratings are generally consistent with the characteristics of differences between the samples.

\section{Results and discussion (Correlation between coal intrinsic characteristics and $R_{70}$ method)}

Having an in-depth understanding of the correlation between coal intrinsic characteristics and the SCC liability is a very important issue in coal mine management. This science is mandatory for detecting and preventing the occurrence of the SCC phenomenon. Coal intrinsic 


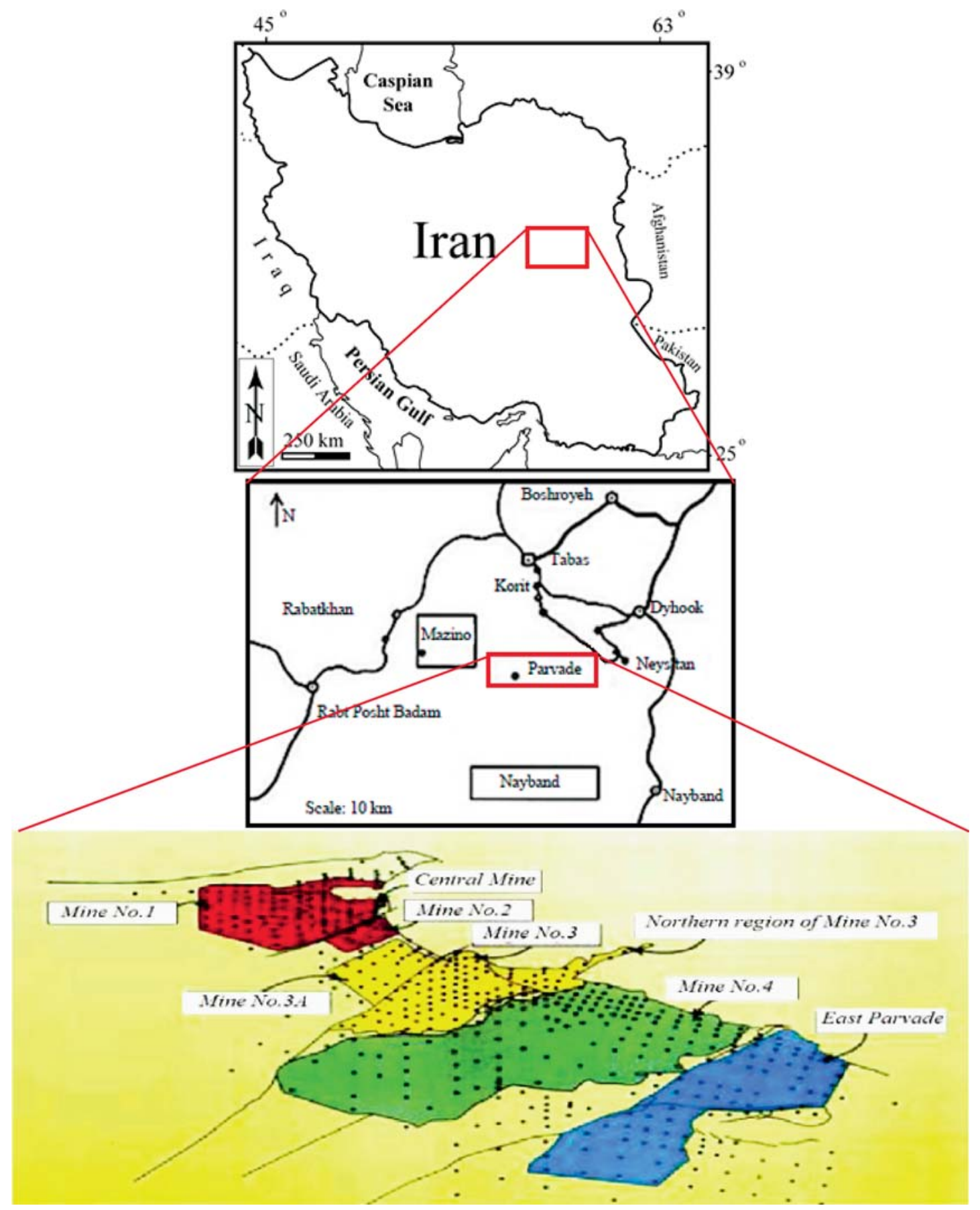

Figure 6: Geographical location of the Tabas Parvadeh coal mine

characteristics can have an effect on this phenomenon, some of which accelerate this process and other characteristics decelerate this process. Hence, based on the relationship regression between these characteristics and R70 values, the correlation study was carried out. The intrinsic parameters were determined and R70 was taken as an independent variable; the results of the correlation study are plotted in Figures 10-a to 10-h, the relationships were described and their role was determined.

The $\mathrm{R}^{2}$ values were utilized to measure the trends and any noteworthy connections between the intrinsic prop- erties and R70 index. The study interpreted the relationship between the intrinsic properties and the SCC liability index based on the set criterion, which are presented in Table 3. The effect of coal intrinsic characteristics on the SCC is described in the following sections.

\subsection{The mutual effect of moisture and pyrite contents}

The tests performed show that moisture and pyrite content play a very important role in the initiation of the 
SCC. So, the SCC accelerates with the combination of pyrite and moisture at the same time. It acts as an important foundation for the SCC (Figures 10-a and 10-b).

In Figures 10-a and 10-b, the correlation displays $\mathrm{R}^{2}$ of 0.913 and 0.9309 for moisture content and pyrite content with R70 values, respectively. Based on Table 3, the correlation between moisture content and R70 values is a strong relationship and the correlation between pyrite content and R70 values is a perfect relationship.

Pyrite acts as an effect as its oxidized product accelerates the rate of oxidation of natural mixes present in coal. The pyrite oxidation prompts the formation of ferric ions which catalyses the reaction, as shown in Equations 4 to 7, and Figure 11. Additionally, pyrite oxida-

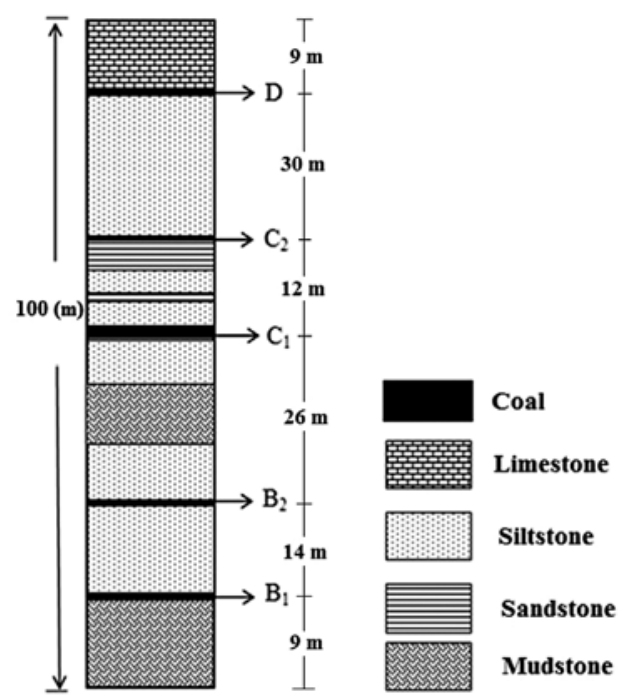

Figure 7: Tabas coal basin stratigraphic column (Sereshki et al., 2016; Mohtasham Seyfi et al., 2018) tion results in swelling which in turn causes breakage of the coal particles expanding the surface area for enhanced oxidation.

The specific heat of pyrite is only one-third of that of coal; but with the same heat absorption, the temperature rise of pyrite is three times higher when compared to coal (Deng et al., 2015). Moreover, pyrite does not react effectively without the presence of moisture and in a dry state does not contribute to the thermal runaway process (Arisoy and Beamish, 2015).

Coal with increasingly reactive pyrite content does not achieve thermal runaway any faster in a dry state, but it does in a moist state. So, the key exothermic pyrite reaction occurs with oxygen within the presence of moisture.

Several equations for the reactions of pyrite, oxygen, and moisture are available in the past researches. For example, the reaction for pyrite oxidation has been given in Equations 4 to 7.

$$
\begin{gathered}
\mathrm{FeS}_{2}+8 \mathrm{H}_{2} \mathrm{O}+\frac{7}{2} \mathrm{O}_{2} \rightarrow \\
\rightarrow \mathrm{FeSO}_{4} \cdot 7 \mathrm{H}_{2} \mathrm{O}+\mathrm{H}_{2} \mathrm{SO}_{4}(\Delta \mathrm{H}=-1465.49 \mathrm{~kJ})
\end{gathered}
$$

(Weise Jr et al., 1987)

$$
\mathrm{FeS}_{2}+8 \mathrm{H}_{2} \mathrm{O}+7 \mathrm{O}_{2} \rightarrow \mathrm{FeSO}_{4} \cdot 7 \mathrm{H}_{2} \mathrm{O}+\mathrm{SO}_{4}{ }^{2-}+2 \mathrm{H}^{+}
$$

(Beamish et al., 2012)

$$
\begin{gathered}
\mathrm{FeS}_{2}+7 \mathrm{O}_{2}+16 \mathrm{H}_{2} \mathrm{O} \rightarrow \\
\rightarrow 2 \mathrm{H}_{2} \mathrm{SO}_{4}+2 \mathrm{FeSO}_{4} \cdot 7 \mathrm{H}_{2} \mathrm{O}+1321 \mathrm{~kJ}
\end{gathered}
$$

(Arisoy and Beamish, 2015)

$$
\mathrm{FeS}_{2} \stackrel{\mathrm{O}_{2}+\mathrm{H}_{2} \mathrm{O}}{\longrightarrow} \mathrm{FeSO}_{4} \underset{\mathrm{O}_{2}+\mathrm{H}_{2} \mathrm{O}+\mathrm{FeS}_{2}}{\stackrel{\mathrm{O}_{2}+\mathrm{H}_{2} \mathrm{O}}{\rightleftarrows}} \mathrm{Fe}_{2}\left(\mathrm{SO}_{4}\right)_{3}
$$

(Deng et al., 2015)

\section{Coal Properties Analysis}

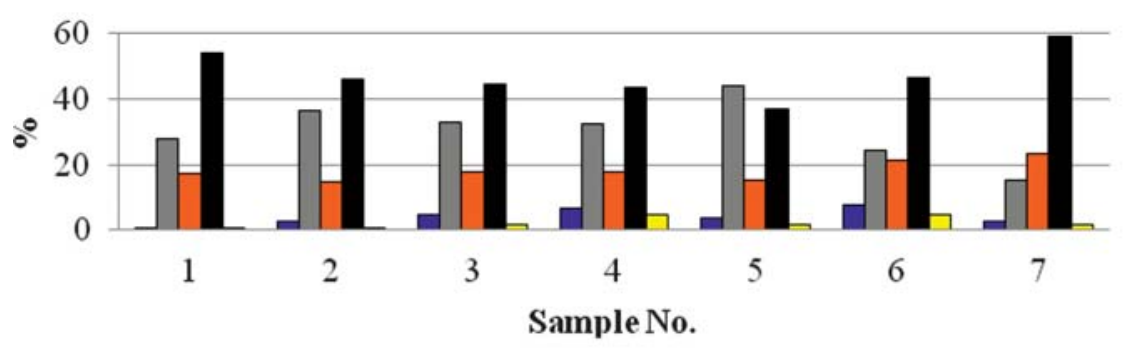

a Moisture Content (\%)

$\square$ Ash Content (\%)

$\square$ Volatile Matter (\%)

- Fixed Carbon (\%)

$\square$ Pyrite Content (\%)

Sample No.

\section{Coal Macerals Analysis}

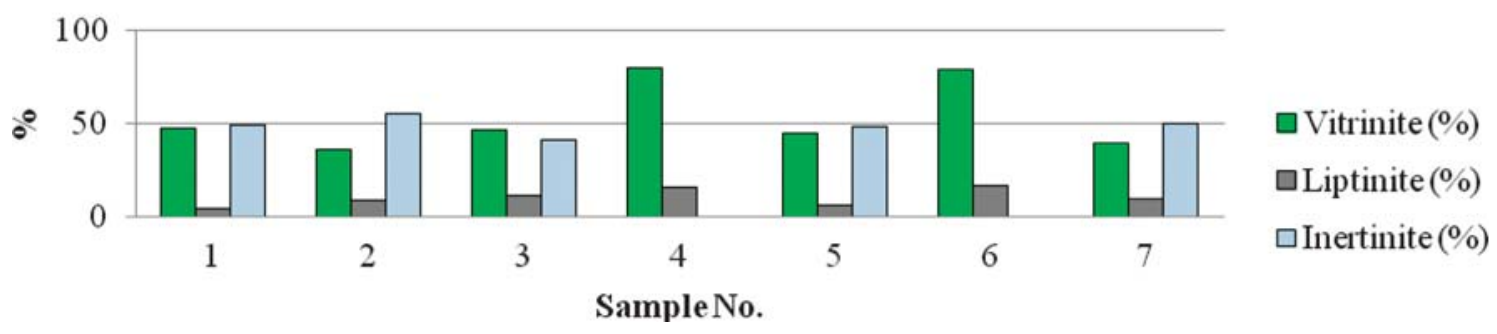

Figure 8: The proximate and petrographic characterization analysis of Tabas Parvadeh coal mines 


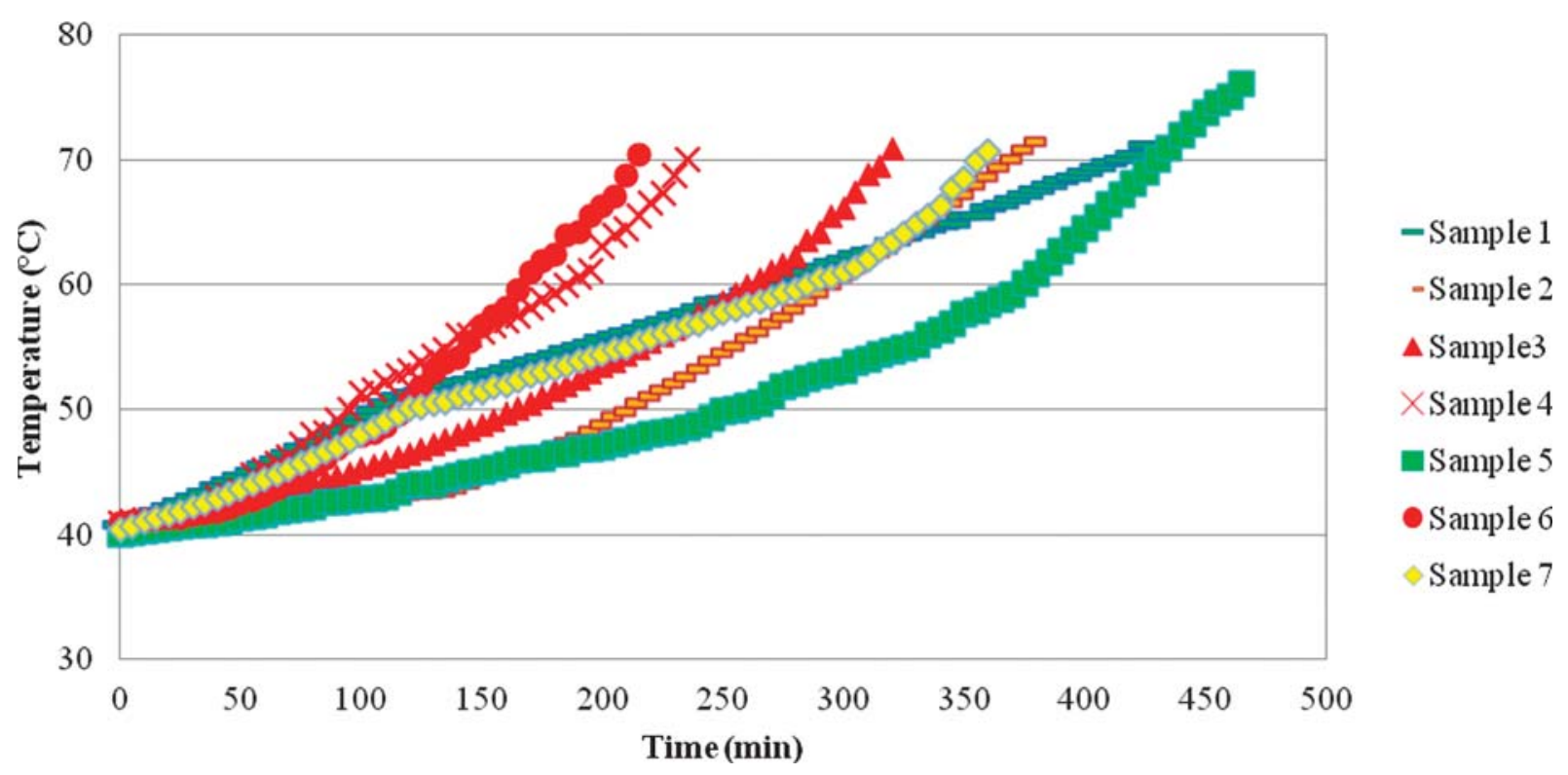

Figure 9: Curves of R7o test results for Tabas Parvadeh coal mines samples

Table 2: Values of R7o $\left({ }^{\circ} \mathrm{C} / \mathrm{h}\right)$ test method in Tabas Parvadeh coal mines samples

\begin{tabular}{|l|l|l|l|l|l|l|l|}
\hline Sample No. & 1 & 2 & 3 & 4 & 5 & 6 & 7 \\
\hline Parvadeh No. & Parvadeh 1 & Parvadeh 1 & Parvadeh 2 & Parvadeh 2 & Parvadeh 2 & Parvadeh 3 & Parvadeh 4 \\
\hline Seam- Panel & C1-W3 & C1-E3 & C1-Block 4 & B1-Block 3 & B2-Block 2 & C1-Block 1 & C1-Block 1 \\
\hline R70 Values $\left({ }^{\circ} \mathrm{C} / \mathrm{h}\right)$ & 4.27 & 4.92 & 5.65 & 7.74 & 4.20 & 8.34 & 5.00 \\
\hline Class $($ Queensland) & V & V & V & V & V & VI & V \\
\hline Class (New South Wales) & IV & IV & IV & IV & IV & V & V \\
\hline
\end{tabular}

Table 3: Criterion set for factors affecting the SCC liability (Glantz et al., 1990; Rumsey, 2015; Onifade and Genc, 2018)

\begin{tabular}{|l|l|l|}
\hline Category & Criterion & Remarks \\
\hline 1 & $\begin{array}{l}\mathrm{R}^{2} \text { between } \\
0.95 \text { and } 1\end{array}$ & $\begin{array}{l}\text { Variable indicates a perfect } \\
\text { relationship }\end{array}$ \\
\hline 2 & $\begin{array}{l}\mathrm{R}^{2} \text { between } \\
0.51 \text { and } 0.94\end{array}$ & $\begin{array}{l}\text { Variable indicates a strong } \\
\text { relationship }\end{array}$ \\
\hline 3 & $\begin{array}{l}\mathrm{R}^{2} \text { between } \\
0.25 \text { and } 0.50\end{array}$ & $\begin{array}{l}\text { Variable indicates a moderate } \\
\text { relationship }\end{array}$ \\
\hline 4 & $\begin{array}{l}\mathrm{R}^{2} \text { between } \\
0.1 \text { and } 0.24\end{array}$ & $\begin{array}{l}\text { Variable indicates a weak } \\
\text { relationship }\end{array}$ \\
\hline 5 & $\begin{array}{l}\mathrm{R}^{2}<0.1 \text { but } \\
\text { not zero }\end{array}$ & $\begin{array}{l}\text { Variable indicates a very weak } \\
\text { relationship }\end{array}$ \\
\hline 6 & $\mathrm{R}^{2}$ of zero & $\begin{array}{l}\text { Variable indicates no } \\
\text { relationship at all }\end{array}$ \\
\hline
\end{tabular}

The above equations suggest that oxygen and moisture are two prime weathering parameters, which add to the pyrite modification and additionally prompt the formation of sulphuric acid as a by-product of the alteration process. The presence of moisture doubles the reactivity rate of coal and the presence of pyrite in dispersed form 10 fold the actual reaction rate.

These reactions can occur at low temperatures and also, all of the reactions are exothermic reactions. The heat generated from these reactions doubles that of coal with similar oxygen (Garcia et al., 1999; Martínez et al., 2009). As shown in Figure 12, the existence of moisture and pyrite contents on coal can accelerate the process and this is a big promoter for the occurrence of the SCC, which is described based on Equations 4 to 7.

\subsection{Effect of ash content}

In Figure 10-c, the general trend effect of ash content on the SCC using the R70 test method is shown. Based on Table 3 , the $\mathrm{R}^{2}$ is moderate in this correlation $\left(\mathrm{R}^{2}\right.$ is 0.2901 ), based on literature, there is a decrease in the R70 values and an increase in the time to reach the thermal runaway as the ash content in the coal increases, and the SCC potential decreases (Kaymakci and Didari, 2002; Beamish and Blazak, 2005). It is evident that there is a negative relationship between ash content and the SCC potential. This means that as ash content increases, the SCC liability decreases. This relationship is due to the ash content in the coal acting as a heat sink and so it absorbs heat from oxidation reactions, and ash content prevents coal temperature from rising.

\subsection{Effect of volatile matter}

In Figure 10-d, the effect of volatile matter on the SCC using the R70 test method is shown. The $\mathrm{R}^{2}$ value 


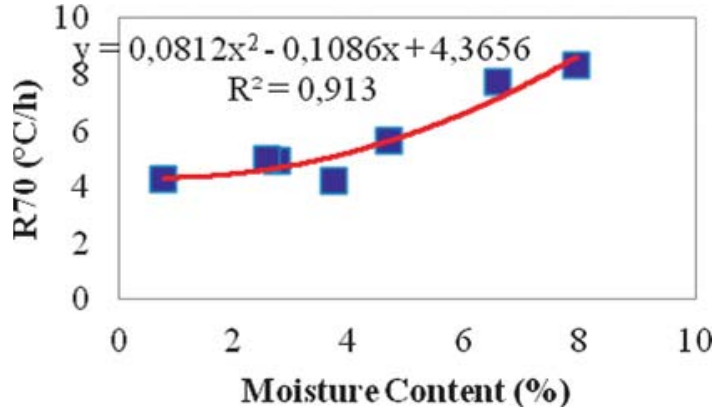

Figure 10-a: Results of correlation between moisture content and R7o values

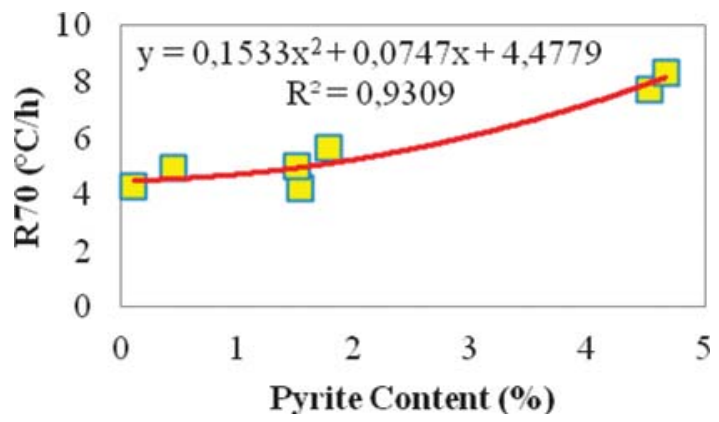

Figure 10-b: Results of correlation between pyrite content and R7o values

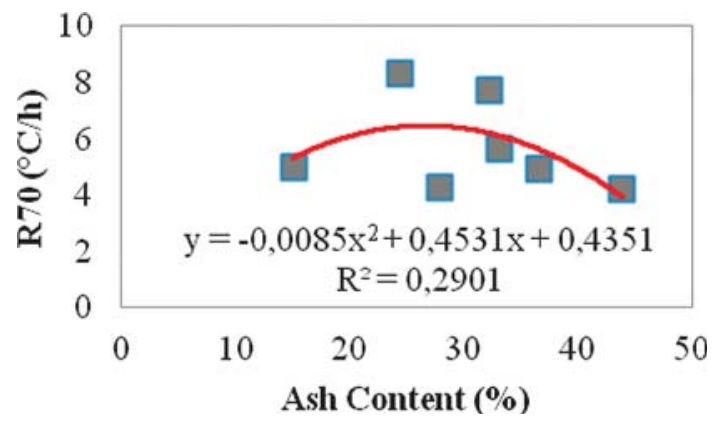

Figure 10-c: Results of correlation between ash content and R7o values

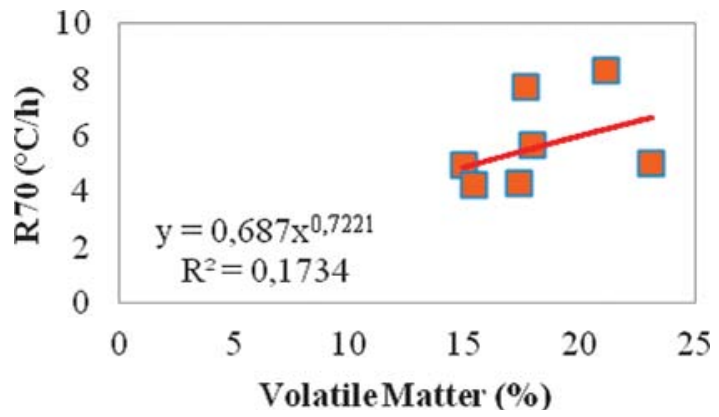

Figure 10-d: Results of correlation between volatile matter and $R_{70}$ values

for volatile matter is considered 0.1734 . Based on Table $\mathbf{3}$, this is an indication that volatile matter has a weak effect size. Based on literature, as the volatile matter increases, the oxidation capacity of coals is more likely to

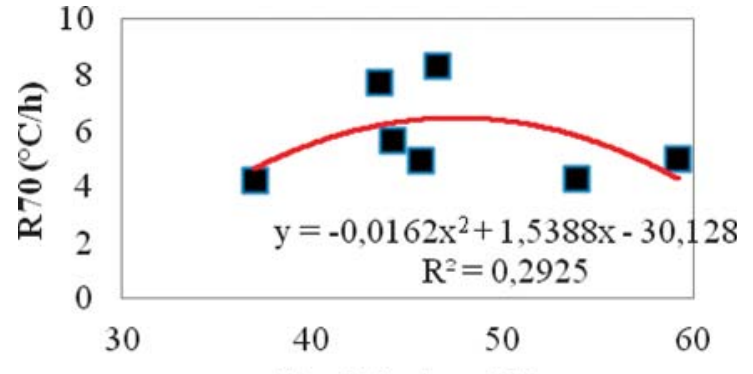

Fixed Carbon (\%)

Figure 10-e: Results of correlation between fixed carbon and $R 70$ values

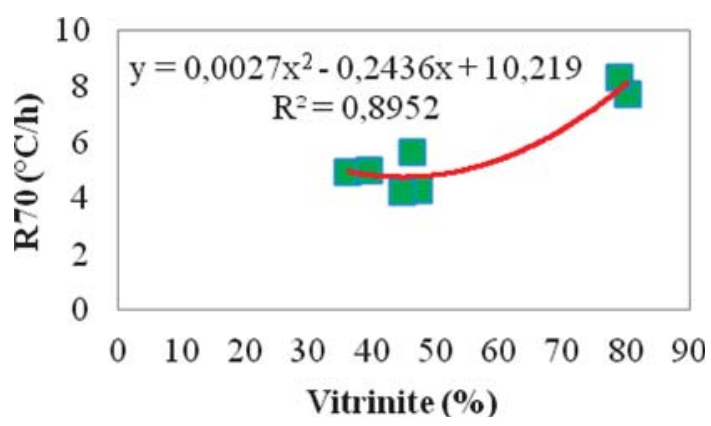

Figure 10-f: Results of correlation between vitrinite and $R_{70}$ values

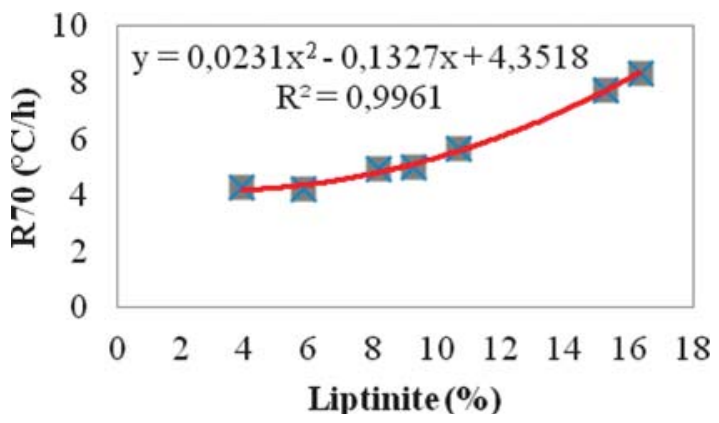

Figure 10-g: Results of correlation between liptinite and $R_{70}$ values

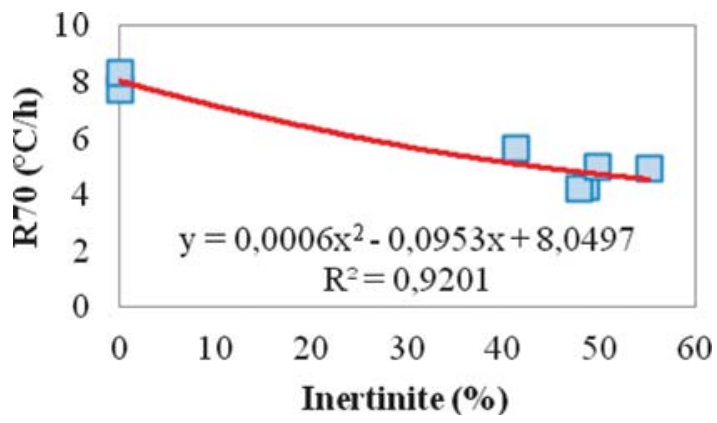

Figure 10-h: Results of correlation between inertinite and R7o values

increase in general (Raju, 1988; Chandra and Prasad, 1990). So, the R70 values are increased and the SCC potential is enhanced. This relation is due to the volatile matter acting as a fuel and this forms one of the sides of 


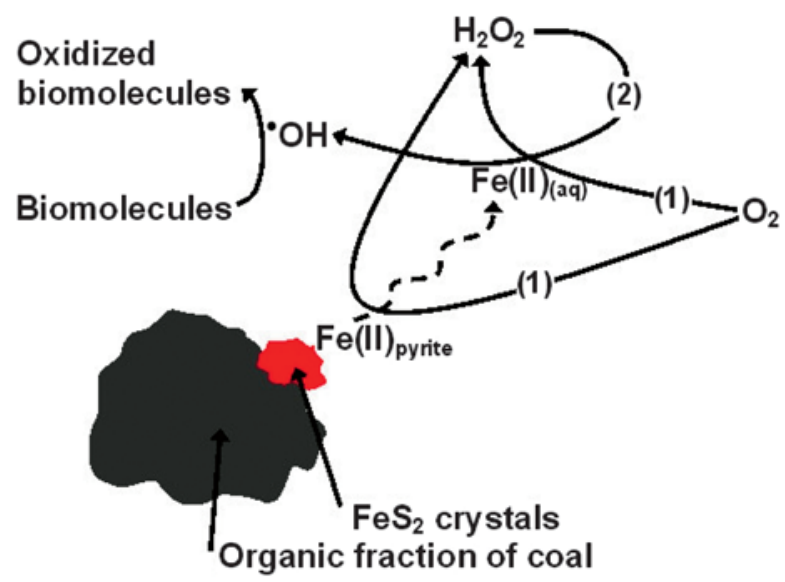

(1) $\mathrm{O}_{2}+\mathrm{Fe}$ (II) $\rightarrow \mathrm{Fe}(\mathrm{III})+\left(\mathrm{O}_{2}{ }^{\circ}\right)^{-}$ $\mathrm{Fe}(\mathrm{II})+\left(\mathrm{O}_{2}^{*}\right)^{-}+2 \mathrm{H}^{+} \rightarrow \mathrm{Fe}(\mathrm{III})+\mathrm{H}_{2} \mathrm{O}_{2}$

(2) $\mathrm{H}_{2} \mathrm{O}_{2}+\mathrm{Fe}(\mathrm{II}) \rightarrow \mathrm{Fe}(\mathrm{III})+\mathrm{OH}^{-}+{ }^{\cdot} \mathrm{OH}$

Figure 11: Effect of pyrite content on accelerating the SCC mechanism

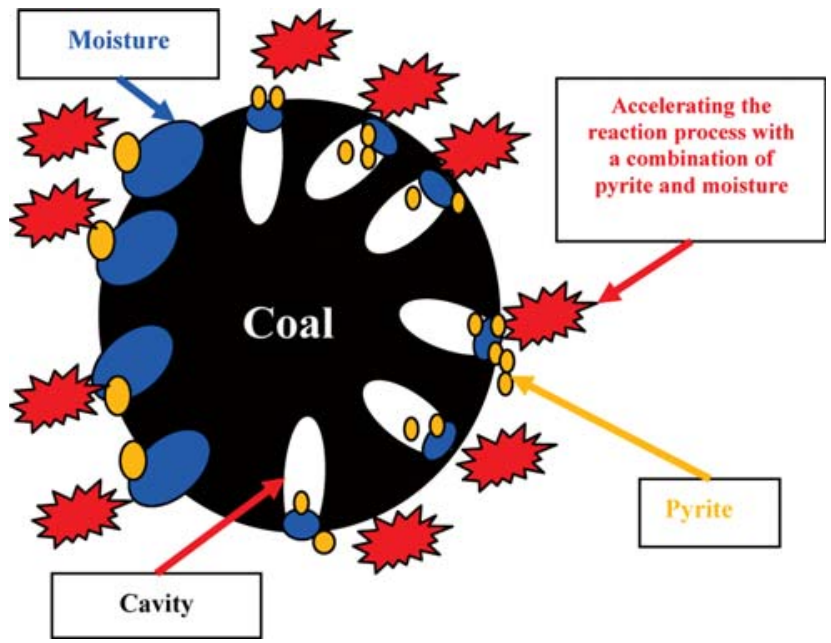

Figure 12: Effect of moisture and pyrite on accelerating the SCC mechanism (Saffari et al., 2019b)

the fire triangle. So, in coal samples with a high volatile matter, the propensity of the SCC is increased.

\subsection{Effect of fixed carbon}

In Figure 10-e, the general trend effect of fixed carbon on the SCC using the R70 test method is shown. The $\mathrm{R}^{2}$ is moderate in this correlation $\left(\mathrm{R}^{2}\right.$ is 0.2925$)$ and based on literature, with an increase of fixed carbon on coals, the R70 values are decreased and the SCC potential decreases (Beamish et al., 2001; Beamish, 2005). It has been known that the low rank coals (low fixed carbon) have a high propensity to spontaneously combust because these coals will have high moisture and high volatile matter contents in comparison to the high rank coals.

\subsection{Effect of macerals content}

Coal macerals are classified into three major organic groups, vitrinite, liptinite, and inertinite based on their compounds. One of these classifications is given by Van Krevelen (1961) and shown in Figure 13. The plot shows the differences between macerals, the variation within macerals and the changes in their composition with increasing coalification (Saffari et al., 2019c, d).

As seen in Figure 13, liptinite, and vitrinite have a higher $\mathrm{H} / \mathrm{C}$ and $\mathrm{O} / \mathrm{C}$ ratio in comparison to inertinite, respectively. The existence of $\mathrm{H}$ and $\mathrm{O}$ in coal accelerates the SCC potential (Michalski et al., 1990). So, the existence of liptinite and vitrinite in coal samples causes a higher SCC potential. The effect of macerals on the SCC using the R70 test method is shown in Figures 10-f to $\mathbf{1 0 - h}$, which will be followed in more detail in further subsections.

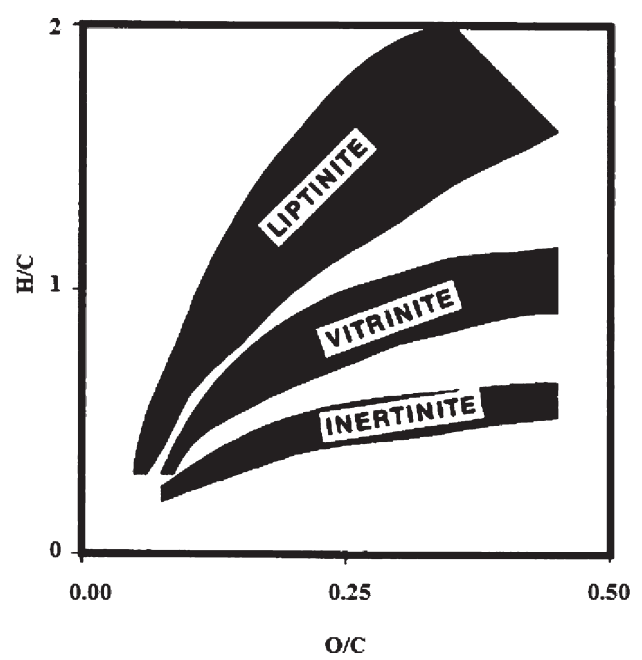

Figure 13: A Van Krevelen plot showing approximate bands for the three main maceral groups (Van Krevelen, 1961)

\subsubsection{Vitrinite Group}

The main characteristics of the vitrinite group are described by Stach (1982), and Chaudhuri (2016). The most critical processes of vitrinite formation from precursors are humification and gelification. Humification includes moderately dynamic oxidation, which might be quickened by the expansion of oxygen. In the presence of oxygen, the lignin is first assaulted by wood destroying fungi and then aerobic bacteria and is converted into a humic substance. Moreover, these groups of macerals have a higher $\mathrm{H} / \mathrm{C}$ and $\mathrm{O} / \mathrm{C}$ ratio (see Figure 13), thus the existence of $\mathrm{H}$ and $\mathrm{O}$ in coal accelerates the SCC potential. In Figure 10-f, the results of the vitrinite fit R70 values are shown, and $\mathrm{R}^{2}$ based on Table 3 is strong in this correlation $\left(\mathrm{R}^{2}\right.$ is 0.8952$)$. The results show that with an increase in vitrinite in coal samples, the sustainability of these coals to spontaneously combust is enhanced. 


\subsubsection{Liptinite Group}

The main characteristics of the liptinite group are described by Stach (1982), and Chaudhuri (2016). It originates from relatively hydrogen-rich plant material, and generally, liptinite contents have high hydrogen content, which influences the technological properties of coal (Chaudhuri, 2016).

Also, this type of maceral has a higher $\mathrm{H} / \mathrm{C}$ and $\mathrm{O} / \mathrm{C}$ ratio (see Figure 13), thus the existence of $\mathrm{H}$ and $\mathrm{O}$ in coal accelerates the SCC potential. So, coal with a high percentage of liptinite contents is sustainable to SCC. In Figure 10-g, the results of liptinite fit R70 values are shown, and $\mathrm{R}^{2}$ based on Table 3 is perfect in this correlation $\left(\mathrm{R}^{2}\right.$ is 0.9961$)$. The results show that with an increase of liptinite in a coal sample, the sustainability of these coals to spontaneously combust is enhanced, and $\mathrm{R} 70$ values are increased.

\subsubsection{Inertinite Group}

The main characteristics of the inertinite group are described by Stach (1982), and Chaudhuri (2016). The chemical composition of inertinite shows a higher carbon and lower oxygen and hydrogen content, in contrast to vitrinite (Van Krevelen, 1993). So their rank is higher in comparison to the macerals of the vitrinite and liptinite groups (Chaudhuri, 2016).

Also, this type of maceral has a lower $\mathrm{H} / \mathrm{C}$ and $\mathrm{O} / \mathrm{C}$ ratio in comparison to liptinite, and vitrinite (see Figure 13). So, coal with a high percentage of inertinite content is not sustainable for the SCC. In Figure 10-h, the results of the inertinite fit $\mathrm{R} 70$ values are shown, and $\mathrm{R}^{2}$ based on Table 3 is strong in this correlation $\left(\mathrm{R}^{2}\right.$ is $0.9201)$. The results show that with an increase in the inertinite content in a coal sample, the sustainability of these coals to spontaneously combust is decreased, and R70 values are also decreased.

\section{Conclusions}

The SCC is one of the worst hazards in coal industries. So, a better understanding of the tendency of the SCC could be a great advantage in the schematization of coal mining. Hence, in this study, the SCC propensity was measured experimentally using the R70 test method in Tabas Parvadeh coal mines, and statistical analysis was done. The statistical analysis showed that the SCC liability of coals can be determined by various intrinsic factors.

The results show that the B1 seam in Parvadeh II and C1 seam in Parvadeh III have a high potential of the spontaneous combustion of coal, which is due to high moisture content, high pyrite content, high vitrinite content, high liptinite content, and no inertinite content, in comparison to the other seams in the other mines in Tabas Parvadeh.
The following findings are drawn from the present investigations:

1. It has been discovered that a precise characterization of the level of oxidation could be a helpful instrument to quantify the relative liability of coals toward the SCC.

2. Statistical analysis reveals that R70 and coal characteristics analysis have a coefficient of determination (moisture $\left(\mathrm{R}^{2}=0.913\right)$, pyrite $\left(\mathrm{R}^{2}=0.9309\right)$, ash $\left(\mathrm{R}^{2}=\right.$ $0.2901)$, volatile matter $\left(R^{2}=0.1734\right)$, fixed carbon $\left(R^{2}=\right.$ $0.2925)$, vitrinite $\left(R^{2}=0.8952\right)$, liptinite $\left(R^{2}=0.9961\right)$, inertinite $\left.\left(\mathrm{R}^{2}=0.9201\right)\right)$; and can be used to predict the SCC of coal, but moisture, pyrite, vitrinite, liptinite, and inertinite contents have a high influence on the liability of coal to spontaneously combust in this coalfield.

3. An increase in moisture, pyrite, vitrinite, liptinite, and volatile matter contents enhances the SCC potential in Tabas Parvadeh coal mines.

4. From the statistical analysis, the results show that the propensity of Tabas Parvadeh coals to spontaneously combust decreases with an increase in the content of ash, fixed carbon, and inertinite.

5. The outcomes achieved in this investigation might be utilized as a reliable tool to support previous work on the role of inherent properties on the SCC.

\section{References}

Afzal, P. (2018): Comparing ordinary kriging and advanced inverse distance squared methods based on estimating coal deposits; case study: East-Parvadeh deposit, central Iran. Journal of Mining and Environment. 9, 3, 753-760.

Ahangaran, D.K., Afzal, P., Yasrebi, A.B., Wetherelt, A., Foster, P.J. and Darestani, R.A. (2011): An evaluation of the quality of metallurgical coking coal seams within the north block of Eastern Parvadeh coal deposit, Tabas, Central Iran. Journal of Mining and Metallurgy A: Mining, 47, 1, 9-24.

Arisoy, A. and Beamish, B. (2015): Mutual effects of pyrite and moisture on coal self-heating rates and reaction rate data for pyrite oxidation. Fuel, 139, 107-114.

Beamish, B. (2005): Comparison of the R70 self-heating rate of New Zealand and Australian coals to Suggate rank parameter. International Journal of Coal Geology, 64, 1-2, 139-144.

Beamish, B. and Blazak, D.G. (2005): Relationship between ash content and R70 self-heating rate of Callide Coal. International Journal of Coal Geology, 64, 1-2, 126-132.

Beamish, B., Barakat, M.A. and George, J.D.S. (2001): Spontaneous combustion propensity of New Zealand coals under adiabatic conditions. International Journal of Coal Geology, 45, 2-3, 217-224.

Beamish, B., Edwards, D. and Theiler, J. (2018): Implementation of Interactive Spontaneous Combustion Hazard Assessment and Management at Meandu Mine. Coal Operators' Conference. University of Wollongong. Australia. pp. 329-335. 
Beamish, B., Lin, Z. and Beamish, R. (2012): Investigating the influence of reactive pyrite on coal self-heating. Coal Operators' Conference. University of Wollongong. Australia. pp. 294-299.

Beamish, B.B., Barakat, M.A. and St George, J.D. (2000): Adiabatic testing procedures for determining the self-heating propensity of coal and sample ageing effects. Thermochimica Acta, 362, 1-2, 79-87.

Chandra, D. and Prasad, Y.V.S. (1990): Effect of coalification on spontaneous combustion of coals. International Journal of Coal Geology, 16, 225-229.

Chaudhuri, S.N. (2016): Coal Macerals. In: Tiess G., Majumder T., Cameron P. (eds) Encyclopedia of Mineral and Energy Policy. Springer, Berlin, Heidelberg. pp. 1-6.

Cliff, D., Rowlands, D. and Sleeman, J. (1996): Spontaneous Combustion in Australian Underground Coal Mines, Edited by C. Bofinger, Safety in Mines Testing and Research Station, Brisbane, Australia. 165 P.

Deng, J., Ma, X., Zhang, Y., Li, Y. and Zhu, W. (2015): Effects of pyrite on the spontaneous combustion of coal. International Journal of Coal Science \& Technology, 2, 4, 306-311.

Garcia, P., Hall, P.J. and Mondragon, F. (1999): The use of differential scanning calorimetry to identify coals susceptible to spontaneous combustion. Thermochimica acta, 336, 1-2, 41-46.

Glantz, S.A., Slinker, B.K. and Neilands, T.B. (1990): Primer of applied regression and analysis of variance (Vol. 309). New York: McGraw-Hill. 949 P.

Humphreys, D., Rowlands, D. and Cudmore, J.F. (1981): Spontaneous combustion of some Queensland coals. In Proceedings of Ignitions, Explosions and Fires in Coal Mines Symposium (pp. pp5-1 - 5-19). The AusIMM Illawarra Branch, Melbourne, Australia.

Karsner, G.G. and Perlmutter, D.D. (1982): Model for coal oxidation kinetics. 1. Reaction under chemical control. Fuel, 61(1), 29-34.

Kaymakci, E. and Didari, V. (2002): Relations between coal properties and spontaneous combustion parameters. Turkish Journal of Engineering \& Environmental Sciences, 26, 59-64.

Lang, L. and Fu-Bao, Z. (2010): A comprehensive hazard evaluation system for spontaneous combustion of coal in underground mining. International Journal of Coal Geology, 82, 1-2, 27-36.

Martínez, M., Márquez, G., Alejandre, F. J., Del Río, J. J. and Hurtado, A. (2009): Geochemical study of products associated with spontaneous oxidation of coal in the Cerro Pelado Formation, Venezuela. Journal of South American Earth Sciences, 27, 2-3, 211-218.

Medunić, G., Mondol, D., Rađenović, A. and Nazir, S. (2018): Review of the latest research on coal, environment, and clean technologies. Rudarsko-geološko-naftni zbornik (The Mining-Geology-Petroleum Engineering Bulletin), 33, 3, 13-21.

Michalski, S.R., Winschel, L.J. and Gray, R.E. (1990): Fires in abandoned coal mines. Bulletin of the Association of Engineering Geologists, 27, 4, 479-495.
Mohtasham Seyfi, M., Khademi Hamidi, J., Monjezi, M. and Hosseini, A. (2018): Estimation of coal seams gas content for evaluating potential use of methane drainage system in Tabas coal mine. Journal of Mining and Environment, 9, 3, 667-677.

Onifade, M. and Genc, B. (2018): Modelling spontaneous combustion liability of carbonaceous materials. International Journal of Coal Science \& Technology, 5, 2, 191-212.

Raju, G.S.N. (1988): Auto oxidation in Indian coal mines- an investigation. J. Mine Met. Fuels, 9, 437-441.

Rumsey, D.J. (2015): U Can: statistics for dummies. John Wiley \& Sons. $528 \mathrm{P}$.

Saffari, A., Ataei, M., Sereshki, F. and Naderi, M. (2019 a): Environmental impact assessment (EIA) by using the Fuzzy Delphi Folchi (FDF) method (case study: Shahrood cement plant, Iran). Environment, Development and Sustainability, 21, 817-860.

Saffari, A., Sereshki, F. and Ataei, M. (2019 c): Evaluation effect of macerals petrographic and pyrite contents on spontaneous coal combustion in Tabas Parvadeh and Eastern Alborz coal mines in Iran. International Journal of Coal Preparation and Utilization, 1-18. https://doi.org/10.1080/ 19392699.2019.1574261

Saffari, A., Sereshki, F. and Ataei, M. (2019 d): A Comprehensive Study of Effect of Maceral Content on Tendency of Spontaneous Coal Combustion Occurrence. Journal of The Institution of Engineers (India): Series D, 100, 1, 1-13.

Saffari, A., Sereshki, F. and Ataei, M. (2019b): The simultaneous effect of moisture and pyrite on coal spontaneous combustion using CPT and R70 test methods. Rudarskogeološko-naftni zbornik (The Mining-Geology-Petroleum Engineering Bulletin), 46, 3, DOI: 10.17794/rgn.2019.3.6

Saffari, A., Sereshki, F., Ataei, M. and Ghanbari, K. (2013): Applying rock engineering systems (RES) approach to evaluate and classify the coal spontaneous combustion potential in Eastern Alborz coal mines. Int. Journal of Mining \& Geo-Engineering, 47, 2, 115-127.

Saffari, A., Sereshki, F., Ataei, M. and Ghanbari, K. (2017): Presenting an engineering classification system for coal spontaneous combustion potential. International Journal of Coal Science \& Technology, 4, 2, 110-128.

Sereshki, F. and Saffari, A. (2016): Environmental impact assessment and sustainability level determination in cement plants (Case study: Shahrood cement plant). Iranian Journal of Earth Sciences, 8, 2, 90-101.

Sereshki, F., Vaezian, A. and Saffari, A. (2016): Evaluation of the effect of macerals on coal permeability in Tazareh and Parvadeh mines. Journal of Stratigraphy and Sedimentology Researches, 32, 2, 23-34.

Song, Z. and Kuenzer, C. (2014): Coal fires in China over the last decade: a comprehensive review. International Journal of Coal Geology, 133, 72-99.

Stach, E. (1982): Stach's textbook of coal petrology. 3rd ed. Gebr.Borntrager, Berlin/Stuttgart. 535 P.

Thakur, P. (2016): Advanced Reservoir and Production Engineering for Coal Bed Methane. Gulf Professional Publishing. $224 \mathrm{P}$. 
Van Krevelen, D.W. (1961): Coal. Elsevier, Amsterdam. 514 P.

Van Krevelen, D.W. (1993): Coal: Typology-Physics-Chemistry-Constitution (Coal Science \& Technology). Elsevier Science, Amsterdam. 514 P.

Wang, H., Dlugogorski, B.Z. and Kennedy, E.M. (2002): Kinetic modeling of low-temperature oxidation of coal. Combustion and flame, 131, 4, 452-464.

Wang, H., Dlugogorski, B.Z. and Kennedy, E.M. (2003): Pathways for production of $\mathrm{CO}_{2}$ and $\mathrm{CO}$ in low-temperature oxidation of coal. Energy \& fuels, 17, 1, 150-158.

Wiese Jr, R.G., Powell, M.A. and Fyfe, W.S. (1987): Spontaneous formation of hydrated iron sulfates on laboratory samples of pyrite-and marcasite-bearing coals. Chemical Geology, 63, 1-2, 29-38.
Xuyao, Q., Wang, D., Milke, J.A. and Zhong, X. (2011): Crossing point temperature of coal. Mining science and technology (China), 21, 2, 255-260.

Yazdi, M. and Shiravani, A.E. (2004): Geochemical properties of coals in the Lushan coalfield of Iran. International Journal of Coal Geology, 60, 1, 73-79.

Zhang, J., Ren, T., Liang, Y. and Wang, Z. (2016 a): A review on numerical solutions to self-heating of coal stockpile: Mechanism, theoretical basis, and variable study. Fuel, 182, 80-109.

Zhang, Y., Wang, J., Xue, S., Wu, J., Chang, L. and Li, Z. (2016 b): Kinetic study on changes in methyl and methylene groups during low-temperature oxidation of coal via in-situ FTIR. International Journal of Coal Geology, 154, 155-164.

\section{SAŽETAK}

\section{Procjena spontanoga izgaranja ugljena uporabom metoda testiranja R7o na temelju korelacije konstitucijskih svojstava ugljena (primjer rudnika ugljena Tabas Parvadeh, Iran)}

Spontano izgaranje ugljena prirodni je fenomen i glavna opasnost industrije ugljena. Taj fenomen utječe na razne aspekte održivoga razvoja (gubitak života, veliki ekonomski gubitci i onečišćenje okoliša). Svrha je ovoga istraživanja procjena toga fenomena u rudniku ugljena Tabas Parvadeh u Iranu primjenom metode R7o koja se temelji na korelaciji između unutarnjih konstitucijskih značajki ugljena pri postanku. Najprije je ugljen uzorkovan iz ležišta Parvadeh I do IV i određene su konstitucijske značajke ugljena. Zatim je provedena procjena spontanoga izgaranja ugljena upotrebom R7o metode. U posljednjoj fazi određena je korelacija između konstitucijskih značajki ugljena i vrijednosti dobivenih metodom R7o. Rezultati su pokazali da uzorci Bı iz Parvadeh II i C1 iz Parvadeh III imaju visoku sklonost spontanomu izgaranju. Zabilježeno je da povećanje sadržaja vlage, pirita, vitrinita i liptinita povećava tendenciju spontanoga izgaranja ugljena. Dobiveni rezultati imaju velik utjecaj na upravljanje ovim fenomenom u rudnicima Tabas Parvadeh.

\section{Ključne riječi:}

održivi razvoj, spontano izgaranje ugljena, rudnici ugljena Tabas Parvadeh, konstitucijske značajke ugljena, R7o metoda testiranja

\section{Authors contribution}

Amir Safari (Ph.D. Candidate): initialized the idea, completed literature review and participated in all work stages such as providing coal samples, running experimental tests and data analysis. Mohammad Ataei (Full Professor): executed experimental tests, data analysis and test of its accuracy and helped with field work. Farhang Sereshki (Full Professor): managed the whole process and supervised it from the beginning to the end. 